\title{
Effect of fine-grained components on concrete properties and structure formation
}

\author{
Galina Zimakova ${ }^{1, *}$, Valentina Solonina ${ }^{1}$, Marina Zelig $^{1}$, and Viktor Orlov ${ }^{1}$ \\ ${ }^{1}$ Tyumen Industrial University, 625000 Tyumen, Russia
}

\begin{abstract}
The paper investigates the influence of fine-grained components on the synthesis of new formations and structure of cellular concrete. Grain size composition was defined with the aid of a laser diffraction analyzer of particles ANALYSETTE 22 NanoTecplus. The composition of the obtained hydrated phases was studied using electron microscopy and X-ray phase analysis. The introduction of silica and aluminosilicate components with the specific surface area $>350 \mathrm{~m}^{2} / \mathrm{kg}$ enabled to directly influence the mechanism of the hydrated phases formation. Complex hydrated calcium aluminosilicates of the frame structure of zeolite type and non-permanent composition were identified in the hydration products. The formation of the total set of properties is attributed to the morphological features of the hydrated phases, the nature of connections between the crystalline hydrates, and their location in the material structure. X-ray phase analysis showed that ultra-micro-dispersed components have the stimulating impact on the processes of silicate formation. With the increase in the amount of hydrated new formations and decrease in the liquid phase volume the conditions for building of strong crystal intergrowth contacts were created.
\end{abstract}

\section{Introduction}

The latest developments in the field of construction materials science open wide opportunities to control the structure and properties of cement concretes due to introduction of mineral additives, chemically reactive components and modifiers into the binding matrix [1-3]. Such composites as cellular concretes are characterized by composition complexity. Requirements in energy efficiency of building envelopes stimulated the research in the field of autoclaved aerated concrete. However, obtaining of cellular concrete with low density structure predetermines extension of the research on effective control of the structure formation processes. As reported by some of the authors [4-7], the required conditions for minimizing defects in the formed structure of concretes along with provision of the required technical properties are connected with the increase of dispersion of the components and mineral additives. By means of optimal binding content the thickness of intergranular layers is decreased, porosity is also decreased up to a minimum volume and macro-pores transit into micro- and ultrapores.

\footnotetext{
* Corresponding author: zimakovaga@tyuiu.ru
} 
The peculiar features of cement systems with mineral components consist in the variety of chemical and interphase interaction processes in which the additive substances participate along with the cement minerals. Reactive capacity of the mineral additives and components is defined by their chemical and mineral composition, dispersive capacity and the conditions of concrete composite hardening.

Scientific potential of understanding the mechanisms of reaction interaction in multicomponent and multi-level systems (considering their dispersive capacity) which vary in their structure and functional organization grows rapidly [8-11]. However, a number of issues are still being discussed, even though they explain comprehensively the interconnection between the hydration processes and the formation of spatial structures.

Application of fine-grained silica as a component of rheological matrix of type I [12] is considered for powder and powder-activated concretes in modern concrete study. Inclusion of fine-grained silica into the composition of conventional compact-grained concretes is not considered as a relevant issue. Basically, the properties of compact-grained concretes are controlled by introduction of microsilica. Thus, the growth of interest to this material from the side of researchers and manufacturers has lead to the groundless growth of its cost. Application of industrial low-lime ashes in this regards can serve as a technically and economically justified solution.

Previous studies $[13,14]$ have shown that the condition for obtaining heavy cement concrete with high water impermeability (up to grades W16-18) and the strength 45$55 \mathrm{MPa}$ was the method of structure control by means of mechanically activated ash intcorporation in the presence of effective water-reducing additive. High degree of hydration interaction and the formation of monolithic structure are reached resulting from the establishment of strong epitaxial intergrowth contacts, also from formation of the new hydrated phases due to increasing of the pozzolanic activity of ashes. High hydration degree is also attributed to the synthesis of crystals and cluster crystals of hydrated new formations which are naturally connected with each other by the phase intergrowth contacts.

The given paper is aimed to thoroughly study the processes of hydration interaction in cellular cement systems in the presence of mineral additives and fine-grained chemically reactive components in the conditions of hydrothermal treatment.

Hydrothermal hardening conditions allow full accomplishment of reactive capacity of silica components and provide the conditions of interphase interaction. High degree of porosity is peculiar for cellular concrete and therefore justification of the rational composition and technical properties of the mixture is integral in obtaining concretes with the given technical properties. However, description of the hydration hardening processes of the cellular cement systems basically follows the scheme which is indicative of the clinker minerals. Thus, the end products of hydrate formation are generally given as hydrated silicates of various basic capacities. As supposed by the authors of this paper, in a complex system which is subjected to hydrothermal treatment depending on crystalchemical particular features and the dispersity of components the process of the new phases synthesis will have its own peculiar features. A.E. Sheikin shrinkage theory [15] is based on a two-phase model; according to that model the hardened stone is presented by crystal joint and sub-microcrystalline gel.

When clarifying the influence of composition-dispersive properties of the mixture on the processes of hydration interaction and morphological peculiarities of the new hydrated phases we could get the opportunity to control the properties of cellular composites to a greater extend. 


\section{Materials and methods}

The materials used in the given study are as follows: Portland cement with the low content of $\mathrm{C}_{3} \mathrm{~A}(<4.7 \%)$; high-calcium lime; silica sand with $\mathrm{SiO}_{2}$ content $>98 \%$; ash from Reftinsky State District Power Plant [13]; triethanolamine (TEA).

The whole number of aspects influences the structure formation processes and the properties of cellular concretes: concrete composition, water-solid ratio, temperature, the mode and duration of mass maturation, heat performance of autoclaved curing. In order to reach the set objective the following properties were kept permanent: rheological properties of gas-concrete mixture, temperature conditions and the duration of concrete cellular structure formation, the modes of hydrothermal treatment, as well as the consumption of binding material and gas-forming agent.

Silica sand and ash were grinded in a laboratory mill. Silica powder with specific surface area 200,290 and $350 \mathrm{~m}^{2} / \mathrm{kg}$ was preliminary obtained. The specific surface area $350 \mathrm{~m}^{2} / \mathrm{kg}$ was reached by grinding of silica sand in the presence of TEA. The dispersity of grinded ash was $700 \mathrm{~m}^{2} / \mathrm{kg}$. These conditions allowed obtaining micro-heterogeneous and ultra-micro-heterogeneous systems.

The research was conducted using a laser diffraction analyzer of particles size ANALYSETTE 22 NanoTecplus, the facility PSKH-10(SP) (the measuring instrument of the specific surface area and the mean particles size of powders), X-ray diffractometer DRON 7M c $\alpha_{\mathrm{cu}}$, inverted electron optical microscope GX-51.

The new formations of cement composites were identified using the crystallographic and crystal-chemical data bases for minerals and their structural analogues $[16,17]$.

\section{Results}

Results of analytical estimation of the obtained fine-grained silica powders and ash grain composition can be seen in Figure 1.

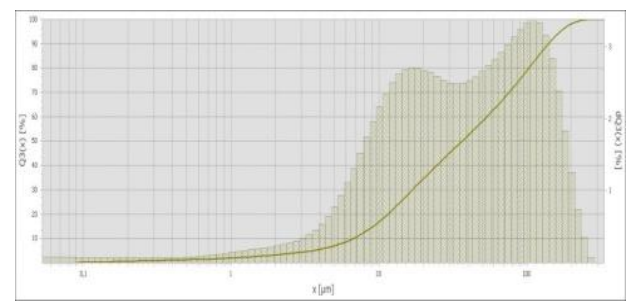

a)

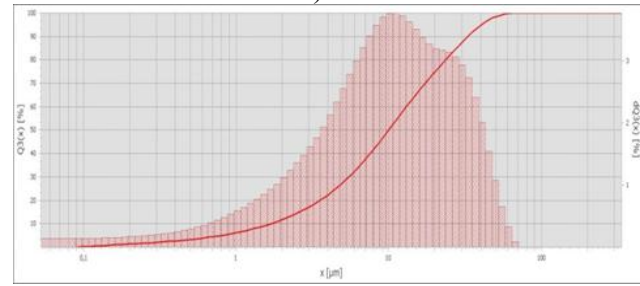

c)

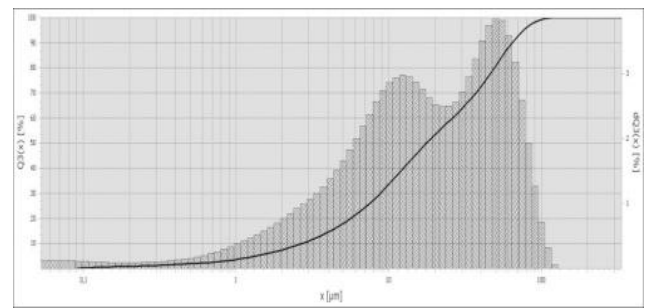

b)

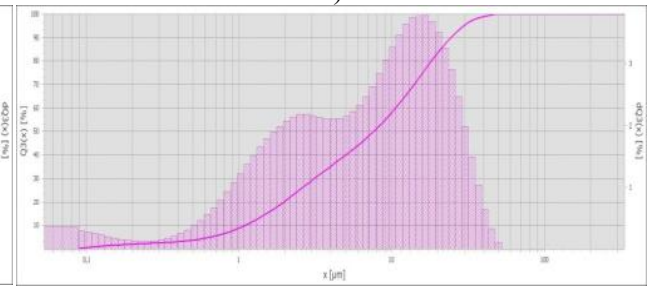

d)

Fig. 1. Grain size composition of fine-grained mineral powders: a) silica powder with the specific surface area of $200 \mathrm{~m}^{2} / \mathrm{kg}$; b) silica powder with the specific surface area of $290 \mathrm{~m}^{2} / \mathrm{kg}$; c) silica powder with the specific surface area of $350 \mathrm{~m}^{2} / \mathrm{kg}$; d) grinded ash with the specific surface area of $700 \mathrm{~m}^{2} / \mathrm{kg}$. 
Silica powder with the specific surface area of $200 \mathrm{~m}^{2} / \mathrm{kg}$ (Fig. 1 a) has $20 \%$ of its grains with the sizes of more than $100 \mu \mathrm{m}$. Integral characteristic of the grain composition indicates predominance of fractions sized 70-150 $\mu \mathrm{m}$, the content of ultra-dispersed grains is insignificant. Every further trial shows that fineness of silica grinding is increasing and the integral curve is shifting towards ultra-dispersed grains. The maximum grain size in silica powder with the specific surface area of $350 \mathrm{~m}^{2} / \mathrm{kg}$ (Fig. 1c) does not exceed $80 \mu \mathrm{m}$; the grains with size $8-40 \mu \mathrm{m}$ are prevailing. The integral curve of grain size composition of grinded ash given in Figure $1 d$ illustrates that the maximum grain size does not exceed $55 \mu \mathrm{m}$; the content of particles of nanometer range reaches $10 \%$. Table 1 provides summary analysis of the particles size of the obtained dispersed materials.

Table 1. Particles size of dispersed materials.

\begin{tabular}{|c|c|c|c|c|}
\hline \multirow{2}{*}{ Material } & \multirow{2}{*}{$\begin{array}{c}\text { Specific } \\
\text { surface, } \mathrm{m}^{2} / \mathrm{kg}\end{array}$} & \multicolumn{3}{|c|}{ The mean particle size, $\mu \mathrm{m}$ in trial bulk } \\
\cline { 3 - 5 } & & $10 \%$ & $50 \%$ & $90 \%$ \\
\hline \multirow{3}{*}{ Silica powder } & 200 & 6.74 & 36.43 & 139.79 \\
\cline { 2 - 5 } & 290 & 2.68 & 17.58 & 64.03 \\
\cline { 2 - 5 } & 350 & 1.68 & 9.97 & 32.83 \\
\hline Grinded ash & 700 & 1.09 & 7.59 & 24.39 \\
\hline
\end{tabular}

5 set of samples were produced and further tested: compositions No.1-3 differed in the dispersion degree of silica powder, compositions No.4 and No.5 had $18 \%$ of silica powder with the specific surface area of $350 \mathrm{~m}^{2} / \mathrm{kg}$ replaced with grinded ash, while TEA was also added into composition No.5 while batching.

Resulting from physical-mechanical testing of samples it was established that concrete strength of the composition No.3 demonstrates almost two-times increase compared to the concrete strength of the composition No.1.

Mineralogy of the new formations was studied in detail with the aim of results justification. Figure 2 presents results of X-ray phase analysis of the obtained cellular concrete samples.
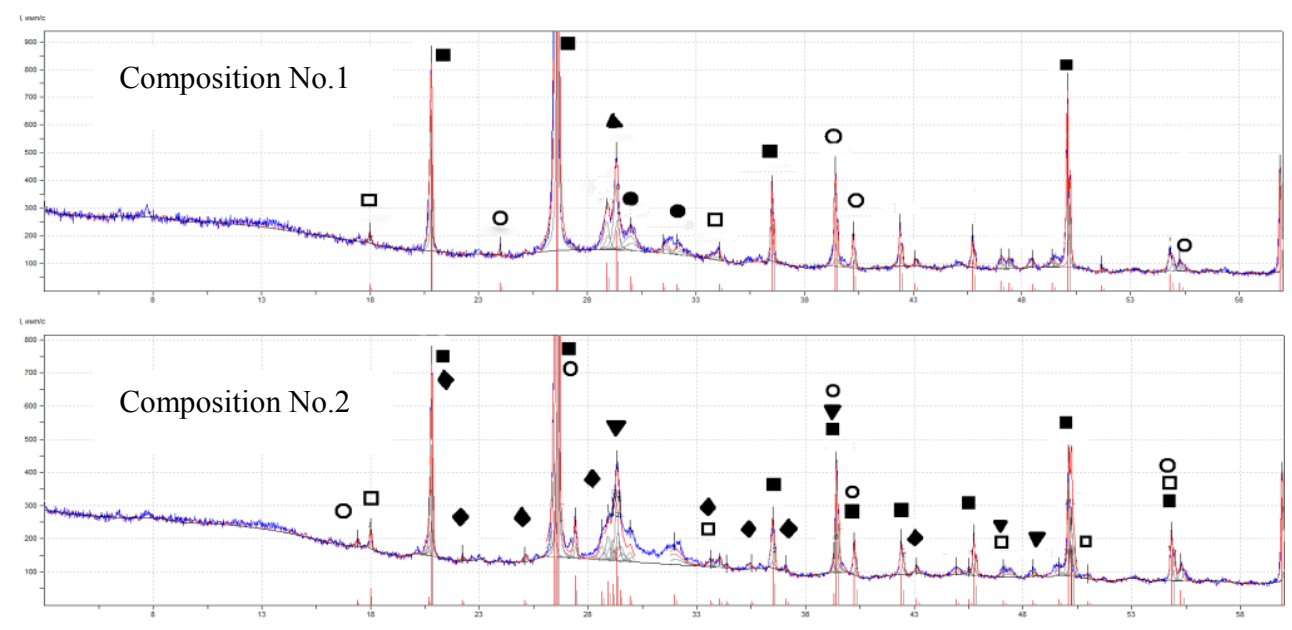

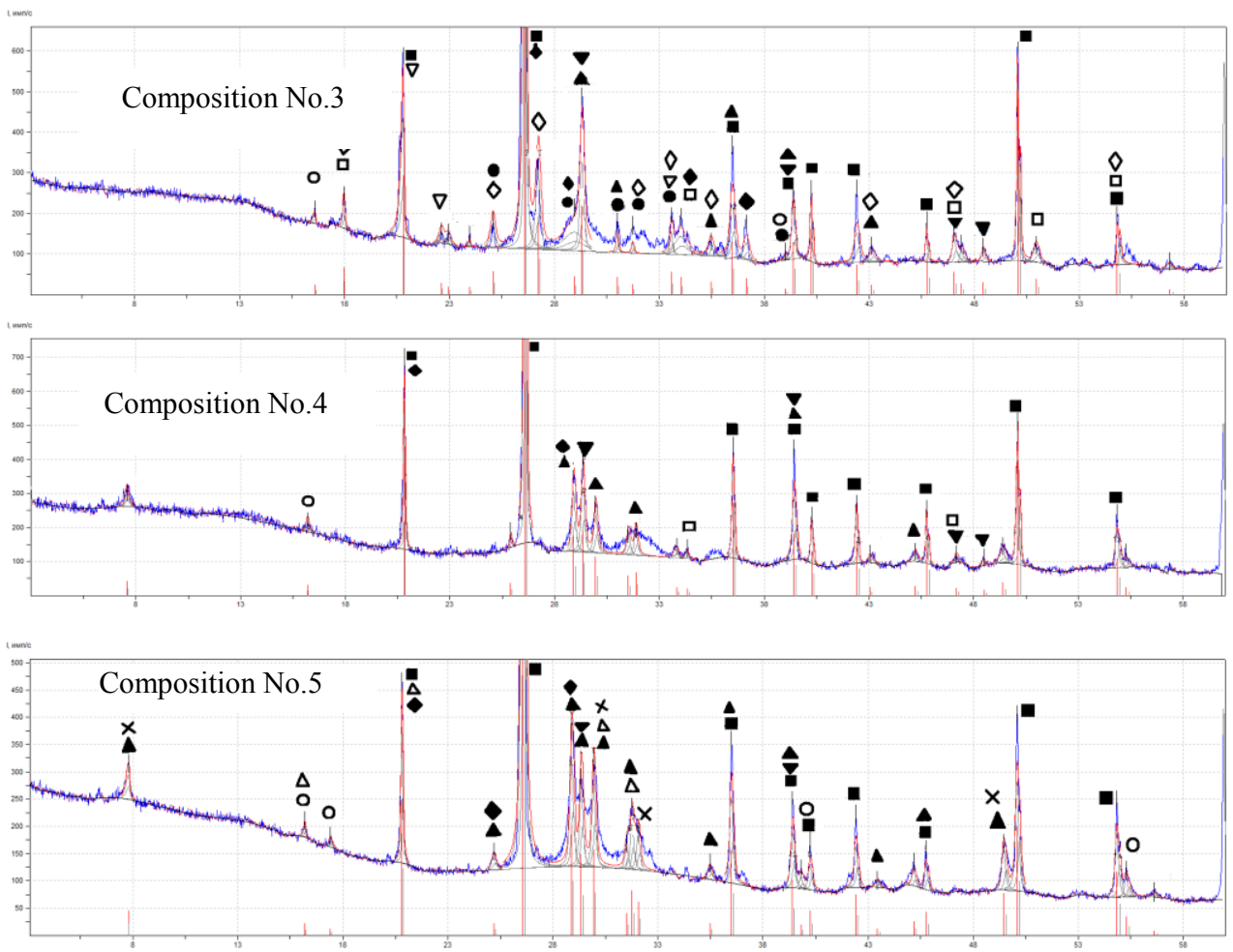

Fig. 2. X-ray phase analysis of the cellular concrete composition: - - silica; $\quad$ - Portlandite; $\nabla$ gismondite; $\diamond$ - xonotlite; $\boldsymbol{\Lambda}$ - monoclinic crystal system tobermorite; $\boldsymbol{\nabla}$ - calcite; $\bullet$ - triclinic tobermorite; - orthorhombic hydrosilicate; o - hydrated calcium aluminate; $\times$ - clinotobermorite; $\Delta$ scolecite.

Resulting from X-ray phase analysis crystal chemical peculiarities of the hydrated phases were defined in micro-heterogeneous system (composition No.1) and ultra-microheterogeneous system (compositions No.3 and No.5). The basic peculiar feature of ultramicro-heterogeneous system was two-times increase of the amount of silica participating in hydrated silicate and hydroaluminosilicate phases synthesis. In the products of hydrothermal hardening of the composition No.1 orthorhombic hydrated silicates $2 \mathrm{CaO} \cdot \mathrm{SiO}_{2} \cdot 2 \mathrm{H}_{2} \mathrm{O}$ were detected, along with monoclinic crystal system tobermorite and Portlandite. Polysilicates of various structures, like triclinic tobermorite, xonotlite were crystallized in the composition No.3 due to high reactive capacity of silica-oxygen anions.

In the presence of TEA solubility of the basic mineral constituents of the cement was changed. As noted in $[18,19]$ TEA mainly increases the solubility of aluminate phases. In this system in the hydration products the formation of frame hydroaluminosilicates of gismondite type $\mathrm{CaO} \cdot \mathrm{Al}_{2} \mathrm{O}_{3} \cdot 2 \mathrm{SiO}_{2} \cdot 4-5 \mathrm{H}_{2} \mathrm{O}$ of monoclinic crystal system was revealed.

In the presence of grinded ash in the composition No.4 full binding of Portlandite into hydrated silicates could be observed. In this case hydrated silicates formed a continuous series of xonotlite-tobermorite type, including both high-basic and low-basic xonotlite phases. Also, the presence of hydrated calcium aluminates was established.

Composition No.5 differed by replacement of $18 \%$ silica sand with ash and additional introduction of TEA. The synthesis of new phases revealed frame hydrated silicates of scolecite type $\mathrm{CaO} \cdot \mathrm{Al}_{2} \mathrm{O}_{3} \cdot 3 \mathrm{SiO}_{2} \cdot 3 \mathrm{H}_{2} \mathrm{O}$. 
It can be seen from the X-ray patterns that decreasing the particles diameter not only intensified the participation of silica in new phases synthesis, but also it had lead to changing of their morphology with the formation of monoclinic, triclinic, orthogonal hydrated silicates and hydrated calcium aluminates. Application of fine-grained silica in combination with TEA stimulates the increase of the balance of hydrated phases with formation of the minerals which are similar in their structure to natural zeolites. Crystalchemical properties of the revealed new phases are given in Table 2 and illustrated in Figures 3, 4 .

Table 2. Crystal-chemical properties of the new phases.

\begin{tabular}{|c|c|c|c|c|c|}
\hline \multirow{2}{*}{$\begin{array}{c}\text { Name of the } \\
\text { identified phase }\end{array}$} & Chemical formula & \multicolumn{3}{|c|}{ Cell parameters, $\AA$ : } & Cell volume, \\
\cline { 3 - 5 } & & $\mathrm{a}$ & $\mathrm{b}$ & $\mathrm{c}$ & $\mathrm{V}_{\mathrm{c}}, \AA^{3}$ \\
\hline $\begin{array}{c}\text { Orthorhombic } \\
\text { tobermorite }\end{array}$ & $2 \mathrm{CaO} \cdot \mathrm{SiO}_{2} \cdot 2 \mathrm{H}_{2} \mathrm{O}$ & 5.5860 & 3.6960 & 22.7790 & 470.29 \\
\hline $\begin{array}{c}\text { Monoclinic } \\
\text { crystal system } \\
\text { tobermorite }\end{array}$ & $2 \mathrm{CaO} \cdot \mathrm{SiO}_{2} \cdot 2 \mathrm{H}_{2} \mathrm{O}$ & 6.6900 & 7.3900 & 22.7790 & 939.21 \\
\hline $\begin{array}{c}\text { Triclinic } \\
\text { tobermorite }\end{array}$ & $5 \mathrm{CaO} \cdot 6 \mathrm{SiO}_{2} \cdot \mathrm{H}_{2} \mathrm{O}$ & 11.1560 & 7.3030 & 9.5660 & 763.87 \\
\hline Xonotlite & $6 \mathrm{CaO} \cdot 6 \mathrm{SiO}_{2}(\mathrm{OH})_{2}$ & 16.5300 & 7.3300 & 7.0400 & 853.00 \\
\hline Gismondite & $\mathrm{CaO} \cdot \mathrm{Al}_{2} \mathrm{O}_{3} \cdot 2 \mathrm{SiO}_{2} \cdot 4-$ & 10.0200 & 10.6200 & 9.8400 & 1046.16 \\
\hline $5 \mathrm{H}_{2} \mathrm{O}$ & $\mathrm{CaO} \cdot \mathrm{Al}_{2} \mathrm{O}_{3} \cdot 3 \mathrm{SiO}_{2} \cdot 3 \mathrm{H}_{2} \mathrm{O}$ & 18.5080 & 18.9810 & 6.5270 & 2292.79 \\
\hline
\end{tabular}
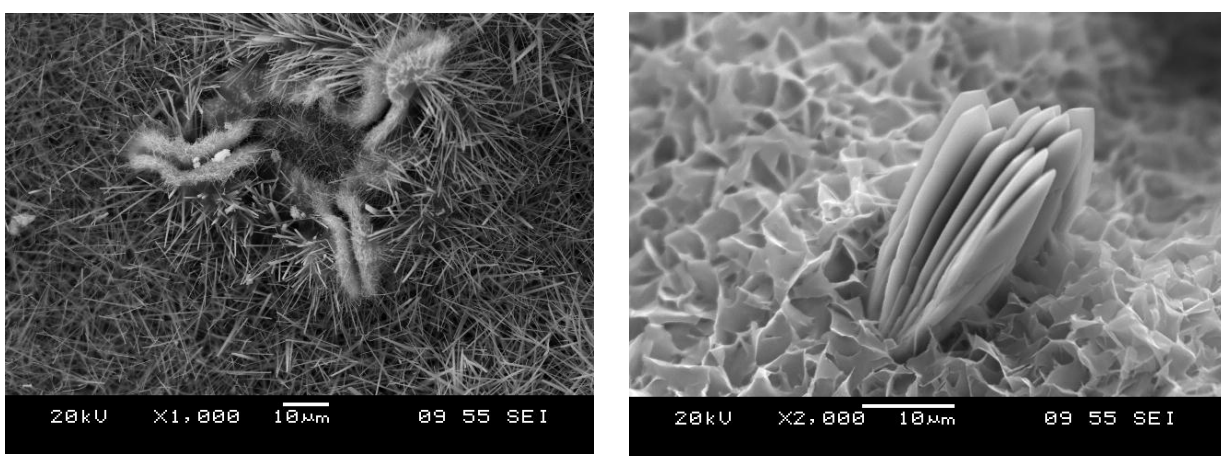

Fig. 3. Hydroaluminosilicates of frame structure.

Electron microscopy data showed that in pores with sizes $50 \mu \mathrm{m}$ and larger, ettringitelike crystals were formed (Fig. 4). During microscopic studies of the obtained samples multiple repetition of their formation was observed, however these crystalline hydrates cannot be revealed by X-ray diffraction analysis. 


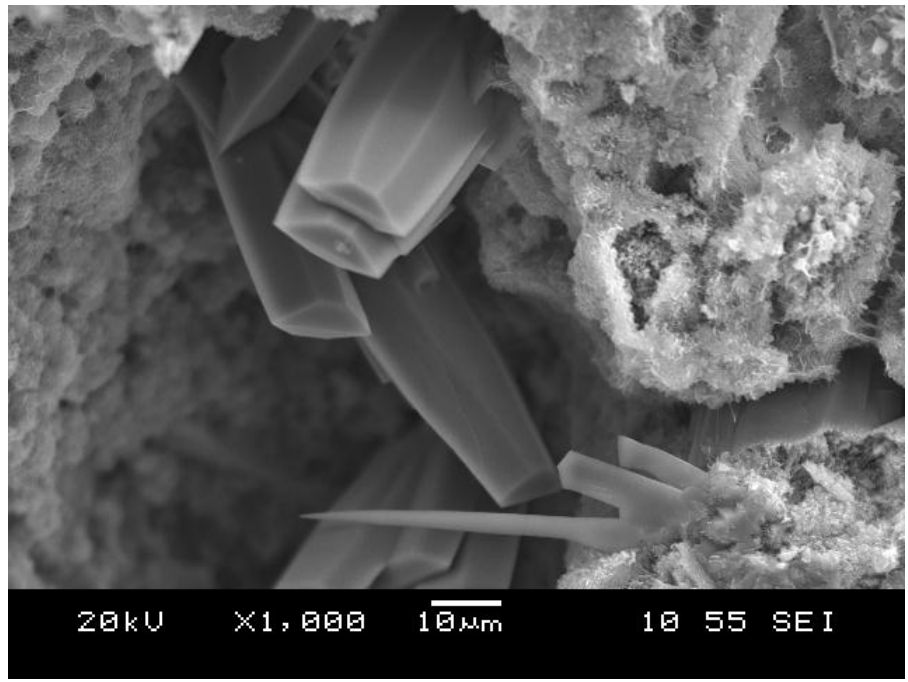

Fig.4. Ettringite-like crystalline hydrates in the pores of cellular concrete.

The gel structural component is subjected to shrinkage, the crystalline joint prevents its free shrinkage, and therefore, while increasing the crystallinity degree of matrix, shrinkage will be defined by elastic properties of the crystalline joint. The presence of tobermorite gel was not established according to the $\mathrm{X}$-ray phase analysis.

Increase in the concrete strength was provided resulting from the formation of cementing components of complex composition with the higher condensation degree of silica-oxygen anions of scolecite, gismondite type, referring to framework silicates of zeolite type.

\section{Conclusion}

Based on the outcome of the present research one can conclude that by means of mechanical activation during grinding up to the specific surface area of $>350 \mathrm{~m}^{2} / \mathrm{kg}$ the potential activity of silica and aluminosilica additives and concrete components increases. Use of TEA allows changing directly the mechanism of hydrated phases formation along with building complex hydrated calcium aluminates of frame structure of zeolite type with non-permanent composition and similar structure. When increasing dispersion and partly replacing silica with ash, up to $70 \%$ of silica and up to $100 \% \mathrm{Ca}(\mathrm{OH})_{2}$ participate in new phases synthesis. Hydrated silicates of xonotlite-tobermorite type build a continuous series of crystalline structures.

Further investigation will involve studying the influence of fillers dispersion capacity and mineral additives on the morphology of crystalline hydrates which are formed during hydration of cement and silicate systems. The study will also address the development of new compositions of dry building mixtures and special purpose concrete.

\section{References}

1. J.W. Bullard, H.M. Jennings, R.A. Livingston, A. Nonat, G.W. Scherer, J.S. Schweitzer, K.L. Scrivener, J.J. Thomas, Cem. Concr. Res. 41, 1208 (2011)

2. N. van Tuan, G. Ye, K. van Breugel, O. Copuroglu, Cem. Concr. Res. 41(11), 1104 (2011) 
3. S. Pashkevich, A. Pustovgar, A. Adamtsevich, A. Eremin, Appl. Mech. Mater. 584585, 1659 (2014)

4. Yu.M. Bazhenov, V.S. Demyanova, V.I. Kalashnikov, Modificirovannye vysokokachestvennye betony [Modified high-quality concretes] (Association of universities for civil engineering, Moscow, 2006) (in Russian)

5. V.G. Batrakov, Modificirovannye betony. Teorija i praktika [Modified concretes. Theory and practice] (Strojizdat, Moscow, 1998) (in Russian)

6. I.N. Akhverdov, Osnovy fiziki betona [Fundamentals of concrete physics] (Strojizdat, Moscow, 1981) (in Russian)

7. S.S. Kaprielov, Beton i zhelezobeton [Concrete and Reinforced Concrete] 4, 16 (1995) (in Russian)

8. H. Taylor, J. Amer. Ceramic Soc. 69 (6), 464 (1986)

9. B. Lothenbach, G. Le Saout, M. Ben Haha, R. Figi, E. Wieland, Cem. Concr. Res. 42(2), 410 (2012)

10. S. M. Leisinger, B. Lothenbach, G. Le Saout, C. Annette Johnson, Cem. Concr. Res. 42, 158 (2012)

11. M.K. Takhirov, Proceedings of MIIT: New in building materials science 902, 48 (1997) (in Russian)

12. V.I. Kalashnikov, Beton i zhelezobeton [Concrete and Reinforced Concrete] 1, 82 (2012) (in Russian)

13. G.A. Zimakova, V.A. Solonina, M.P. Zelig, IOP conf. series: Earth and Environmental Science 50, 012007 (2017)

14. G.A. Zimakova, V.A. Solonina, M.P. Zelig, International Research Journal 12-3 (54), 90 (2016) (in Russian)

15. A.E. Shejkin, Ju.V. Chehovskij, M.I. Brusser, Struktura i svojstva cementnyh betonov [Structure and properties of cement concretes] (Strojizdat, Moscow, 1979) (in Russian)

16. WWW-MINCRYST, Crystallographic and crystallochemical database for minerals and their structural analogs, available at http://database.iem.ac.ru/mincryst/rus/ (1997) (in Russian)

17. V.S. Gorshkov, V.V. Timashev, V.G. Savelyev, Metody fiziko-himicheskogo analiza vjazhushhih veshhestv [Methods of physico-chemical analysis of binders] (Vysshaja shkola, Moscow, 1981) (in Russian)

18. V. Ramachandran, Shestoj mezhdunarodnyj kongress po himii cementa $\left[\right.$ The $6^{\text {th }}$ International Congress on Chemistry of Cement] 2(2), 37 (Strojizdat, Moscow, 1976)

19. E. Gartner, D. Myers, J. Am. Ceram. Soc. 76 (6), 1521 (1993) 